\title{
Parasosial dan Romantic Beliefs: Studi pada Penonton Serial Drama Korea
}

\author{
Dona Syafrina, Dian Putri Permatasari, Yuliezar Perwira Dara \\ donasyafrina@yahoo.com \\ Jurusan Psikologi, Universitas Brawijaya, Malang, Indonesia
}

\begin{abstract}
Penelitian ini merupakan penelitian kuantitatif yang bertujuan untuk mengetahui hubungan antara parasosial dengan romantic beliefs pada penonton serial drama Korea. Penelitian ini dilakukan terhadap 107 penonton serial drama Korea berusia 18-25 tahun. Hasil analisis data menunjukkan koefisien korelasi product moment $(\mathrm{r})$ sebesar $0.601(\mathrm{p}=0.00)$. Berdasarkan hasil penelitian menunjukkan bahwa terdapat hubungan positif yang signifikan antara parasosial dengan romantic beliefs pada penonton serial drama Korea, yang bermakna semakin tinggi tingkat parasosial penonton serial drama Korea maka akan semakin tinggi pula romantic beliefs-nya.
\end{abstract}

Kata kunci: hubungan parasosial; romantic beliefs; serial drama Korea

\section{Pendahuluan}

Kepopuleran Korean Wave atau Hallyu sejak awal tahun 2000-an masih terus merebak di Indonesia. Istilah Hallyu, atau dalam bahasa Inggris disebut dengan Korean Wave, merupakan fenomena demam Korea yang disebarkan melalui budaya pop Korea ke seluruh penjuru dunia lewat media massa, dan yang terbesar adalah lewat jaringan internet dan televisi (Pooe, 2013). Korean Wave di Indonesia dimulai dengan tayangnya drama “Autumn In My Heart” pada tahun 2002 di stasiun televisi Indosiar dan mencapai rating penonton sebesar $11 \%$, yang berarti bahwa sekitar 2,8 juta orang di lima kota besar di Indonesia menonton drama tersebut (Putri, 2013). Sejak awal kepopuleran tersebut hingga tahun 2012, lebih dari 40 drama Korea telah ditayangkan di televisi lokal.

Menurut Rachma (2014), budaya pop Korea menjangkau semua kalangan umur baik anak-anak, remaja, dan dewasa terutama kaum wanita. Survei yang dilakukan oleh Korea Tourism Organization pada tahun 2011 menemukan bahwa 90\% penggemar Hallyu adalah perempuan. Dilihat dari kelompok usia, penggemar kisaran usia dua puluh tahun menempati tempat tertinggi dengan menyumbang persentase sebesar $47 \%$, di mana menurut tahap perkembangan manusia, kisaran usia dua puluh tahun dapat dikategorikan ke dalam tahap emerging adulthood. Menurut Arnett (2000), emerging adulthood adalah tahap perkembangan dalam kehidupan antara remaja dan dewasa muda dengan rentang usia 18-25 tahun. Pada tahap emerging adulthood, individu tidak lagi dinilai sebagai remaja namun belum juga dapat dinilai sebagai dewasa yang bertanggung jawab sepenuhnya bagi dirinya sendiri dan orang lain. Memperluas pandangan terhadap kehidupan, mencari serta menyiapkan karir di masa depan, dan mencari hubungan romantis merupakan hal-hal yang perlu diperhatikan saat seseorang mencapai tahap emerging adulthood (Stephanou, 2012).

Ketika mencari hubungan romantis, setiap orang memiliki pandangan dan ekspektasi masing-masing tentang bagaimana sebuah hubungan yang seharusnya, apa yang harus dilakukan, dan apa yang jangan dilakukan dalam sebuah hubungan romantis. Keyakinan dan konsep seseorang mengenai hubungan romantis dapat dipengaruhi oleh 
cerita yang digambarkan di media massa, termasuk buku, film, dan tayangan televisi. Cerita romantis yang disuguhkan oleh media massa dapat membentuk pandangan penonton yang masih muda mengenai gambaran hubungan romantis bahkan sebelum mereka pernah mengalami hubungan romantis yang sebenarnya (Jin \& Kim, 2015). Kepercayaan atau ekspektasi akan hubungan romantis inilah yang disebut dengan romantic beliefs (Castellini, 2011).

Romantic beliefs berkaitan dengan bagaimana cara kita membangun dan mempertahankan hubungan, serta bagaimana cara kita mengelola konflik yang terjadi dalam sebuah hubungan (Jin \& Kim, 2015). Penelitian yang dilakukan oleh Montgomery (2005) menemukan bahwa individu yang memiliki konstruk romantis yang ideal akan tertarik untuk membangun hubungan romantis yang rekat dan intim, sehingga dapat dikatakan bahwa konstruk ini dapat membantu individu untuk merencanakan dan mempersiapkan hubungan dalam kehidupannya untuk mencapai tingkat kepuasan hubungan yang lebih tinggi. Berpegang pada konstruk romantis yang ideal juga dapat menimbulkan hasil yang negatif. Berdasarkan penelitian, ditemukan bahwa semakin besar perbedaan antara hubungan yang dijalani dengan konstruk romantis ideal seseorang maka ia akan mengalami tingkat kepuasan hubungan yang rendah dan dapat menyebabkan seseorang bertahan lama dalam hubungan yang tidak sehat karena mereka menggunakan alasan romantisme untuk mengabaikan perilaku pasangannya, seperti kekerasan verbal atau fisik (dalam Hefner, 2011).

Romantic beliefs dapat terbentuk dan berkembang melalui pengalaman yang seseorang alami secara langsung maupun tidak langsung. Pengalaman yang tidak langsung di sini dapat berupa terpaan media, baik novel, film, maupun acara televisi. Jin \& Kim (2015) menyampaikan bahwa serial drama dengan genre romance atau romantis adalah jenis drama yang paling populer di Korea dibandingkan dengan serial drama Amerika. Jiang dan Leung (dalam Jin \& Kim, 2015) menekankan bahwa "pure love" atau cinta yang tulus dan hubungan antara karakter utama merupakan karakteristik utama dalam serial drama Korea. Serial drama Korea juga cenderung menggambarkan hubungan romantis dengan sangat ideal dan menekankan makna "true love lasts forever". Pada penelitian yang dilakukan oleh Tuk (2012), dijelaskan bahwa tokoh laki-laki yang romantis dalam drama Korea adalah alasan mengapa drama Korea digemari oleh penonton perempuan yang mengidam-idamkan sosok laki-laki yang sensitif dan gentle. Selain itu, cinta dalam drama Korea ditunjukkan dengan tatapan mata dan sedikit sentuhan serta jarang menunjukkan adegan seksual yang eksplisit, sehingga tontonan drama Korea lebih bisa diterima karena di Indonesia perilaku seksual merupakan bahan yang tabu untuk dibicarakan (Sari, 2014).

Ketika menonton drama, seringkali penonton ikut terbawa suasana, baik itu suasana senang, sedih, maupun kesal seakanakan mereka ikut mengenal karakter drama yang ditonton dan terlibat dalam kehidupan karakter tersebut (Schulze, 2013). Ilusi mengalami interaksi tatap muka dengan karakter dalam tontonan ini kemudian menimbulkan suatu fenomena yang disebut dengan hubungan parasosial (Horton \& Wohl, 1956).

Menurut Horton dan Wohl (1956), hubungan parasosial merupakan hubungan 
tatap muka yang tidak nyata antara penonton dengan orang-orang yang tampil dalam media (baik televisi, radio, maupun internet), di mana penonton merasakan hubungan pertemanan atau hubungan intim yang didasari oleh perasaan ikatan afektif penonton terhadap tokoh media (Sekarsari, 2009). Hal ini terjadi baik terhadap selebriti dalam kehidupan nyata, karakter fiksi yang diperankan oleh aktor, atau bahkan karakter animasi atau kartun (Adam \& Sizemore, 2013). Walaupun terdengar aneh, ternyata hubungan parasosial merupakan suatu hal yang lazim dan dapat dilihat sebagai perluasan dari hubungan sosial dalam kehidupan nyata sehari-hari (Giles, 2002). Hoffner (2008) mengatakan bahwa secara umum, hubungan parasosial dapat memenuhi beberapa kebutuhan emosional dalam hubungan sosial sama seperti interaksi tatap muka. Penelitian juga menemukan bahwa perempuan mengalami hubungan parasosial yang lebih kuat daripada laki-laki (Cohen, dalam Adam \& Sizemore, 2013).

Oleh karena latar belakang yang telah dikemukakan di atas, maka penulis tertarik untuk menguji korelasi antara kecenderungan hubungan parasosial, yang dijalin antara penonton dengan karakter fiktif dalam sebuah drama, dengan romantic beliefs pada individu yang menonton serial drama Korea. Adapun hipotesis dalam penelitian ini yaitu:

- Ho: Tidak terdapat korelasi antara hubungan parasosial dengan romantic beliefs pada penonton serial drama Korea.

- Ha: Terdapat korelasi antara hubungan parasosial dengan romantic beliefs pada penonton serial drama Korea.

\section{Metode}

\section{Jenis penelitian}

Penelitian ini menggunakan metode kuantitatif korelasional untuk melihat korelasi antara hubungan parasosial sebagai variabel bebas dan romantic beliefs pada penonton serial drama Korea sebagai variabel terikat

\section{Partisipan penelitian}

Populasi penelitian ini adalah penonton serial drama Korea. Teknik sampling pada penelitian ini menggunakan purposive sampling. Jumlah sampel pada penelitian ini adalah sebanyak 107 orang, di mana sampel yang diambil merupakan penonton serial drama Korea berjenis kelamin perempuan berusia 18-25 tahun.

\section{Instrumen penelitian}

1. Skala Audience-Persona Interaction oleh Auter dan Palmgreen (2000), yang diterjemahkan dari bahasa Inggris ke bahasa Indonesia.

2. Skala Romantic Beliefs oleh Sprecher dan Metts (1989, dalam Adamczyk \& Metts, 2014), yang diterjemahkan dari bahasa Inggris ke bahasa Indonesia.

\section{Analisis data}

Analisis data menggunakan uji korelasi product moment Pearson yang diolah menggunakan program IBM SPSS Statistics for Mac 24.0.

\section{Hasil}

Berdasarkan data pada Tabel 1, diketahui bahwa bahwa terdapat korelasi yang positif antara hubungan parasosial dengan romantic beliefs pada penonton serial drama Korea dengan nilai signifikansi (p) sebesar 0.00 dan koefisien korelasi product moment $(\mathrm{r})$ sebesar 0.601 .

\section{Diskusi}

Berdasarkan hasil yang didapatkan, diketahui bahwa terdapat hubungan positif 
yang signifikan antara parasosial dengan romantic beliefs pada penonton serial drama Korea. Hasil penelitian yang didapatkan oleh peneliti sesuai dengan hasil penelitian yang dilakukan oleh Jin \& Kim (2015), bahwa terdapat hubungan yang positif antara parasosial dengan romantic beliefs. Hubungan positif antara parasosial dengan romantic beliefs memiliki arti bahwa semakin tinggi seseorang mengalami parasosial dengan suatu karakter, maka semakin tinggi pula kepercayaannya terhadap hubungan romantis (romantic beliefs).

Tabel 1

Hasil uji korelasi

\begin{tabular}{ccccc}
\hline Variabel & Mean & SD & $\begin{array}{c}\text { Nilai } \\
\text { Signifi- } \\
\text { kansi }\end{array}$ & $\begin{array}{c}\text { Nilai } \\
\text { Kore- } \\
\text { lasi }\end{array}$ \\
\hline Parasosial & 75.49 & 12.445 & $0(\mathrm{p}<0.05)$ & 0.601 \\
\hline
\end{tabular}

Pada penelitiannya yang dilakukan pada tahun 2015, Jin \& Kim (2015) mengatakan bahwa ekspektasi seseorang terhadap sebuah hubungan romantis atau romantic beliefs akan terjadi lebih kuat pada orang-orang yang terlibat dalam hubungan parasosial dengan karakter pada sebuah drama. Hal ini dikarenakan sebuah drama memiliki naratif atau jalan cerita yang mengisahkan tentang kehidupan sehari-hari sehingga penonton dapat merasakan perasaan emosional yang lebih kuat dibandingkan dengan program televisi lain seperti berita dan hiburan. Hal ini membuat keterlibatan secara emosional dalam cerita drama dapat membuat penonton lebih sulit untuk membedakan antara kehidupan nyata dan kehidupan yang termediasi (dalam hal ini adalah drama). Serial drama Korea yang memiliki ciri khas dengan genre romantis yang mengisahkan kisah cinta yang berakhir bahagia, ditambah dengan nilai-nilai budaya yang tidak jauh berbeda dengan masyarakat Indonesia pun akhirnya menjadi panutan bagi banyak orang untuk mengetahui seperti apa hubungan romantis yang ideal. Bagi orangorang yang lebih sering menonton drama dan suka membayangkan berhubungan dengan karakter dalam drama, hal-hal yang berkaitan dengan romantic beliefs akan lebih mudah terserap dalam pikiran mereka, dan dapat menyebabkan penonton menganggap bahwa hubungan romantis dalam drama mirip dengan hubungan romantis dalam kehidupan nyata. Selain itu, seseorang yang mengalami hubungan parasosial dengan karakter drama akan cenderung lebih berfokus pada aspekaspek romantis yang diceritakan dalam drama tersebut daripada sisi-sisi negatifnya.

Parasosial adalah hubungan satu arah antara penonton dengan suatu tokoh sebagai hasil dari rekaan media massa, di mana seseorang dapat merasakan keterikatan emosional, bahkan intim, terhadap karakter media. Penelitian ini menemukan bahwa sebagian besar responden, yaitu sebesar $58.9 \%$, termasuk ke dalam hubungan parasosial dengan kategori sedang, sehingga dapat dikatakan bahwa hubungan parasosial yang dialami oleh responden masih tergolong sehat dan normal. Menurut Horton \& Wohl (1956), hubungan parasosial dapat dikatakan patologis hanya apabila hubungan parasosial tersebut dijadikan pengganti dari partisipasi sosial dalam kehidupan nyata dan apabila merujuk pada pemujaan terhadap selebriti (celebrity worship), erotomania (merasa bahwa orang lain memendam perasaan cinta kepada si penderita), atau jika seseorang menguntit figur media.

Dalam penelitian ini, responden terlibat dalam hubungan parasosial karena responden tertarik untuk mengetahui lebih dalam mengenai karakter favoritnya dalam drama, dapat mengidentifikasikan dirinya dengan 
karakter favoritnya, merasa bahwa terdapat kesamaan antara lingkungan pertemanan karakter dalam drama dengan lingkungan pertemanannya dalam kehidupan nyata, dan mengagumi cara karakter favoritnya menyelesaikan masalah.

Menurut Arnett (2000), terdapat tiga isu pada tahap emerging adulthood dan salah satunya adalah mencari pengalaman cinta. Ketika atau bahkan sebelum menjalani sebuah hubungan, biasanya seseorang memiliki kepercayaan atau ekspektasi tentang hubungannya. Hal ini disebut sebagai romantic beliefs. Romantic beliefs dapat terbentuk dan berkembang melalui pengalaman yang seseorang alami secara langsung maupun tidak langsung. Pengalaman yang tidak langsung disini dapat berupa terpaan media, baik novel, film, maupun acara televisi. Bahkan seseorang yang belum pernah mengalami hubungan romantis pun dapat mengetahui bagaimana sebuah hubungan romantis yang seharusnya melalui tontonan yang disajikan oleh media dan kemudian membentuk ekspektasi apabila ia menjalani hubungan romantis di masa depan. Apabila seseorang sudah mengalami hubungan romantis, maka romantic beliefs ini dapat berperan sebagai dasar dari cara berperilaku dan pengambilan keputusan dalam menjalani hubungan.

Beberapa penelitian mengatakan bahwa kepercayaan mengenai hubungan romantis atau romantic beliefs yang dipegang oleh seseorang memiliki hubungan dengan bagaimana sebuah hubungan dapat berkembang dan dipertahankan (Montgomery, 2005; Sprecher \& Metts, 1989; Sprecher \& Metts, 1999; dalam Hefner, 2011). Penelitian oleh Montgomery (2005) mengatakan bahwa seorang lajang yang memiliki konstruk romantis ideal akan cenderung terbuka untuk menjalani hubungan romantis yang rekat dan intim di masa depannya. Romantic beliefs juga berhubungan secara positif dengan kepuasan dan komitmen dalam hubungan. Namun, ada pula penelitian yang mengatakan bahwa adanya perbedaan yang besar antara konstruk ideal dengan pasangan asli berhubungan dengan kepuasan hubungan yang rendah. Selain itu, akan berbahaya apabila seseorang yang terlibat dalam hubungan yang tidak sehat (mengalami kekerasan verbal maupun fisik) berpegang terlalu kuat pada romantic beliefs karena hal tersebut dapat menyebabkan seseorang mengabaikan tindakan kekerasan yang dilakukan oleh pasangannya (Hefner, 2011).

Penelitian ini menemukan bahwa sebagian besar responden, yaitu sebesar $83.2 \%$, termasuk ke dalam romantic beliefs dengan kategori sedang, yang berarti bahwa responden memiliki idealisme tentang hubungan romantis tapi masih dalam batas normal. Berdasarkan hasil penelitian ini maka dapat disimpulkan bahwa semakin tinggi hubungan parasosial yang dialami, semakin tinggi pula romantic beliefs yang dimiliki. Ketika seseorang sering menonton drama, terutama drama dengan genre romantis, ia dapat merasakan perasaan emosional dan terlibat hubungan parasosial dengan karakter favoritnya dalam drama karena merasa memiliki kesamaan dengan lingkungan sosialnya dalam kehidupan nyata, sehingga ketika karakter favoritnya menunjukkan perilaku-perilaku romantis, idealisme orang tersebut terhadap hubungan romantis atau romantic beliefs-nya dapat meningkat.

\section{Daftar Pustaka}

Adam, A., \& Sizemore, B. (2013). Parasocial romance: A social exchange perspective. 
International Journal on Personal Relationships, 7(1), 12-25.

Adamczyk, K., \& Metts, S. (2014). The factor structure of the polish-language version of the romantic beliefs scale. Psihologijske Teme, 23(2), 209-222.

Auter, P. J., \& Palmgreen, P. (2000). Development and validation of a parasocial interaction measure: The audience-persona interaction scale. Communication Research Reports, 17(1), 79-89.

Arnett, J. J. (2000). Emerging adulthood: A theory of development from the late teens through the twenties. American Psychological Association, 55(5), 469480.

Castellini, A. (2011). The role of perfectionism and romanticized beliefs in romantic relationship satisfaction and adjustment. The McNair Scholars Journal of the University of Wisconsin Superior, 12.

Giles, D. C. (2002). Parasocial interaction: A review of the literature and a model for future research. Media Psychology, 4, 279-305.

Hefner, V. (2011). From love at first sight to soul mate: Romantic ideals in popular films and their association with young people's beliefs about relationships. Disertasi. University of Illinois, Illinois.

Hoffner, C. (2008). Parasocial and online social relationships. In S. L. Carvert \& B. J. Wilson (Eds.). The Handbook of Children, Media, and Development. Massachusetts: Blackwell.

Horton, D., \& Wohl, R. R. (1956). Mass communication and parasocial interaction: Observations on intimacy at a distance. Psychiatry: Journal for the Study of Interpersonal Processes, 19, 215-229.

Jin, B., \& Kim, J. (2015). Television drama viewing and romantic beliefs: Considering parasocial interaction and attachment style. International Journal of Humanities and Social Science, 5(10).

Korea Tourism Organization. (2013). Hallyu Wave and Tourism. Seoul: Korea Tourism Organization.

Montgomery, M. (2005). Pyschosocial intimacy and identity from early adolescence to emerging adulthood. Journal of Adolescent Research, 20(3), 346-374.

Pooe, D. S. (2013). Perkembangan korean pop di Gorontalo. Skripsi. Universitas Negeri Gorontalo: Gorontalo.

Putri, T. A. (2013). Pengaruh tayangan drama Korea di Indosiar terhadap minat siswa mempelajari budaya Korea di kalangan Komunitas Nikolas (studi di SMA Negeri 15 Bandung). Tugas Akhir. Universitas Telkom: Bandung.

Rachma, R. R. N. (2014). Korean pop sebagai arena budaya baru (studi pada grup cover dance X-School). Skripsi. Universitas Gadjah Mada: Yogyakarta.

Sari, E. N. P. (2014). Perilaku seksual dan eksploitasi tubuh dalam film horor Indonesia. Skripsi. Universitas Gadjah Mada: Yogyakarta.

Schulze, M. (2013). Korea vs. K-Dramaland: The culturalization of K-Drama by international fans. Acta Koreana, 16(2), 367-397.

Sekarsari, M. (2009). Hubungan antara loneliness dan perilaku parasosial pada 
wanita dewasa muda. Skripsi. Universitas Indonesia: Jakarta.

Stephanou, G. (2012). Romantic relationships in emerging adulthood: Perceptionpartner ideal discrepancies, attributions, and expectations. Psychology, 3(2), 150160. doi: 10.4236/psych.2012.32023.

Tuk, W. (2012). The Korean wave: Who are behind the success of Korean popular culture? Thesis. Leiden University: Leiden. 